\title{
Milnesium minutum and Milnesium sandrae, two new species of Milnesiidae (Tardigrada, Eutardigrada, Apochela)
}

\author{
Giovanni Pilato', Oscar Lisi' \\ I Department of Biological, Geological and Environmental Sciences, University of Catania, Via Androne 81, \\ 95124, Catania, Italy \\ Corresponding author: Giovanni Pilato (pilato@unict.it)
}

Academic editor: S. McInnes | Received 16 September 2015 | Accepted 16 February 2016 | Published 12 April 2016

http://zoobank.org/OD488358-10A0-419F-BFC6-5144A3797F29

Citation: Pilato G, Lisi O (2016) Milnesium minutum and Milnesium sandrae, two new species of Milnesiidae (Tardigrada, Eutardigrada, Apochela). ZooKeys 580: 1-12. doi: 10.3897/zookeys.580.6603

\begin{abstract}
Two new species of Milnesium are described, Milnesium minutum sp. n. from Sicily and Milnesium sandrae sp. n. from the Hawaiian Archipelago. The body size of Milnesium minutum is the smallest of the known species of the genus. The stylet supports are inserted on the buccal tube at $63-66 \%$ of its length and the claws have a [3-3]-[3-3] configuration. Milnesium sandrae has stylet supports inserted on the buccal tube at $58-60.5 \%$ of its length, a [3-3]-[3-3] claw configuration, and the percent ratio between the secondary claw and primary claw length on legs I-III (78.6\%-85.5\%) clearly higher than on legs IV (70.5\%-71.4\%). With the description of these two new species, the number of species in the genus is increased to 31 .
\end{abstract}

\section{Keywords}

Tardigrada, Milnesiidae, new species, Sicily, Hawaiian Archipelago

\section{Introduction}

For 150 years, the genus Milnesium was considered monospecific. Realizing that the individual variability of some characters of Eutardigrada was not as wide as believed for a long time, Binda and Pilato (1990) described a second species of the genus: Milnesium brachyungue Binda \& Pilato, 1990. Subsequently, various authors described many more species. 
In this paper, two new species are described: one, Milnesium minutum sp. n., from two Sicilian localities and the other, Milnesium sandrae sp. n., from Hawai'i Island (Hawaiian Archipelago).

\section{Material and methods}

All studied specimens were mounted in polyvinyl lactophenol. Measurements, in micrometers $(\mu \mathrm{m})$, and photomicrographs were made under x100 oil immersion, using a Leica Phase Contrast Microscope equipped with "Canon S40" digital camera and Adobe Photoshop Elements 2.0 digital imaging software. The $p t$ index (Pilato 1981) is the percent ratio between the length of a structure and the length of the buccal tube. In Milnesiidae, the length of the buccal tube is measured from the anterior margin of the stylet sheaths to the caudal end, including the flexible portion (Tumanov 2006). We measured only specimens that were aligned to provide accurate morphometric measurements; for this reason, when only a small population is available, only few specimens are suitable for measurement. Though this prevents the assessment of statistical analyses, provided the morphological characters are clearly indicative of speciation, this method avoids the sometime questionably large ranges within statistical analyses caused by imprecise measurements. Claw length refers to the maximum length of the external, primary claws correctly oriented with neither bent nor abnormally straight apices. Configuration of the number of claw points on secondary claws (claw configuration) is given according to Michalczyk et al. (2012b).

In addition to the literature descriptions of many species, the following species (deposited in the Binda \& Pilato collection) have been examined for comparison: Milnesium brachyungue Binda \& Pilato, 1990; Milnesium eurystomum Maucci, 1991; Milnesium antarcticum Tumanov, 2006; Milnesium asiaticum Tumanov, 2006; Milnesium longiungue Tumanov, 2006.

\section{Results}

Milnesium minutum sp. n. http://zoobank.org/F90A2415-9C36-4D42-BFF1-C21AE5CE5D20 Fig. 1, Table 1

Type locality. Sicily, Moio Alcantara, Contrada Rinazzo 3754'04"N, 1503'08"E.

Material examined. Moio Alcantara: Contrada Rinazzo (holotype and one paratype: (slide No. 4127) from a moss sample on rock collected by Dr. R. Catanzaro (Catania) (April 1986); Noto: Contrada Volpiglia, (one paratype, slide No. 3238) from a moss sample collected on a dry wall by Mr. S. Di Stefano (Catania) (February 1980).

Type repository. Holotype and two paratypes are deposited in the Binda and Pilato Collection (slides Nos. 4127 and 3238), Museum of the Department of Biological, Geological and Environmental Sciences, University of Catania, Sicily. 

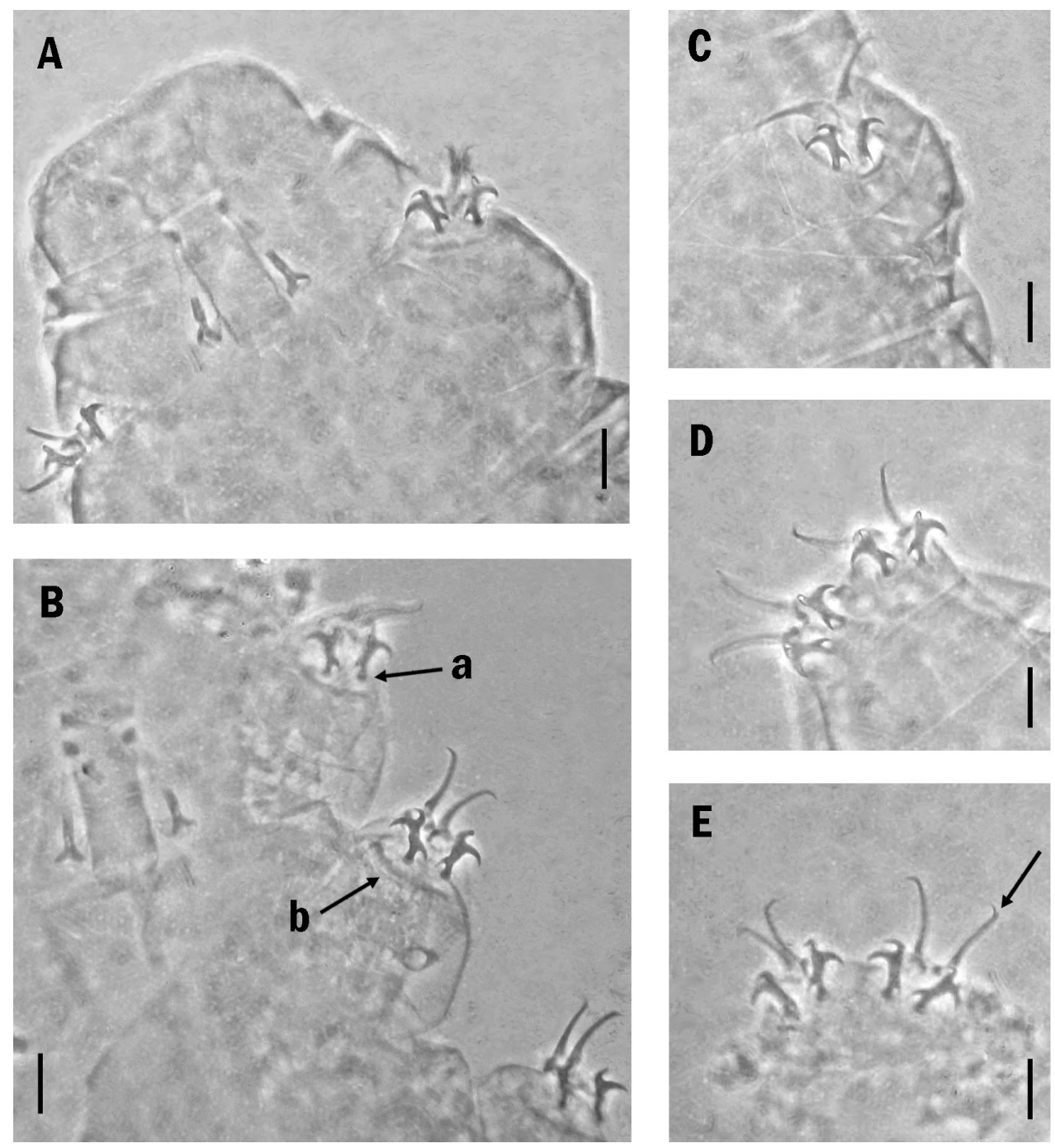

Figure I. A-D Milnesium minutum sp. n. (holotype). A bucco-pharyngeal apparatus B Claws of the second pair of legs; arrow 'a' indicates a claw basal thickening (lunule); arrow 'b' indicates the long cuticular thickening $\mathbf{C}$ Claws of the third pair of legs $\mathbf{D}$ claws of the hind legs $\mathbf{E}$ Claws of the hind legs of a paratype (slide No. 3238) where the accessory points are visible (arrow). Scale bars: $10 \mu \mathrm{m}$.

Specific diagnosis. Body of small size (up about $300 \mu \mathrm{m}$ in the specimens found); colourless; cuticle smooth; eye spots present; six peribuccal and two lateral papillae present; mouth terminal with six triangular peribuccal lamellae with basal stripes; stylet supports inserted on the buccal tube at about $63-66 \%$ of its length; claws of the Milnesium type with a [3-3]-[3-3] configuration; primary claws with thin accessory points; secondary claw bases each with a rounded basal thickening (lunule); a long cuticular bar present under claws I-III. 
Description of the holotype. Body colourless, $288 \mu \mathrm{m}$ long; cuticle smooth without pseudopores, reticulum, tubercles or gibbosities; eye spots present. Six peribuccal and two lateral papillae present. Bucco-pharyngeal apparatus of the Milnesium type (Fig. 1A) (rigid buccal tube without ventral lamina, apophyses for the insertion of the stylet muscles in the shape of very short and flat ridges symmetrical with respect to the frontal plane and without caudal processes; pharyngeal bulb elongated, pear-shaped and without apophyses, placoids or septulum); six triangular peribuccal lamellae present with basal stripes. Wide stylet furcae triangular in shape (Fig. 1A).

Buccal tube cylindrical, $25.7 \mu \mathrm{m}$ long; the external width at the level of the stylet supports insertion point is $10.9 \mu \mathrm{m}(p t=42.4)$. Stylet supports short, inserted on the buccal tube at $65.9 \%$ of its length.

Claws of the Milnesium type (Fig. 1), secondary claw branches with three points: configuration [3-3]-[3-3]. Primary claws on legs II, $11.3 \mu \mathrm{m}$ long $(p t=44.0)$ and secondary claw, $8.0 \mu \mathrm{m}(p t=31.1)$; primary claws on legs III, $11.8 \mu \mathrm{m}$ long $(p t=45.9)$; secondary claw, $8.5 \mu \mathrm{m}$ long $(p t=33.1)$; primary claws on legs IV, $13.1 \mu \mathrm{m}$ long $(p t=$ $51.0)$, secondary claw, $8.6 \mu \mathrm{m}(p t=33.5)$. The secondary claw length is $70.8 \%$ of the primary claw length on legs II, $72.0 \%$ on legs III and $65.6 \%$ on legs IV.

Primary claws with thin accessory points (Fig. 1E arrow); each secondary claw base with rounded basal thickening (lunule) (Fig. 1B, arrow a); a long cuticular bar is present under the claws I-III (Fig. 1B arrow b).

Eggs not found.

Remarks. The paratypes are similar to the holotype in both qualitative and quantitative characters (Table 1).

Etymology. The specific name minutum (minutus = small) refers to the small body size.

Differential diagnosis. Eight species of Milnesium with six peribuccal lamellae and a [3-3]-[3-3] claw configuration are known with a smooth cuticle: Milnesium brachyungue Binda \& Pilato, 1990; Milnesium eurystomum Maucci, 1991; Milnesium asiaticum Tumanov, 2006; Milnesium antarcticum Tumanov, 2006; Milnesium longiungue Tumanov, 2006; Milnesium zsalakoae Meyer \& Hinton, 2010; Milnesium barbadosense Meyer \& Hinton, 2012 and Milnesium bobleberi Bartels, Nelson, Kaczmarek \& Michalczyk, 2014.

Milnesium minutum sp. $\mathrm{n}$. differs from all these species in having a smaller body size, and other character detail indicated in the following comparisons. We noticed that the three specimens we attributed to Milnesium minutum sp. $\mathrm{n}$. are in particular very similar to Milnesium asiaticum and, considering the body size, it was necessary to determine whether they were three young specimens of Milnesium asiaticum or belonged to a different species. Three facts have to be stressed: a) we collected the specimens attributed to the new species in two different localities. b) We examined and measured specimens of the 15 species of Milnesium present in the collection of Binda \& Pilato, and we noticed that for each species in all cases the buccal tube width $p t$ index values for smaller specimens were lower than larger specimens. Specimens of the new Sicilian species with $300 \mu \mathrm{m}$ body length have buccal tube width $p t$ values that are similar to (or slightly higher than) those of Milnesium asiaticum, which have a body length more than twice as long (Tables 1 and 2). c) Milnesium minutum sp. n. differs from Milnesium 
Table I. Measurements in $\mu \mathrm{m}$, $p t$ index values relative to some structures, and percent ratio between secondary claw and primary claw lengths of the holotype and two paratypes of Milnesium minutum sp. $\mathrm{n}$. Also the differences between maximum and minimum values of some characters are given.

\begin{tabular}{|c|c|c|c|c|c|c|c|}
\hline \multirow{3}{*}{ Slide number } & \multicolumn{7}{|c|}{ Milnesium minutum sp. $\mathrm{n}}$. \\
\hline & \multicolumn{2}{|c|}{$\begin{array}{c}4127 \\
\text { Moio Alcantara } \\
\text { Contrada Rinazzo } \\
\text { paratype }\end{array}$} & \multicolumn{2}{|c|}{$\begin{array}{c}4127 \\
\text { Moio Alcantara } \\
\text { Contrada Rinazzo } \\
\text { holotype }\end{array}$} & \multicolumn{2}{|c|}{$\begin{array}{c}3238 \\
\text { Noto } \\
\text { Contrada Volpiglia } \\
\text { paratype } \\
\end{array}$} & \multirow[t]{2}{*}{$\begin{array}{l}\text { Difference between } \\
\text { Max.-Min. } \\
\text { values }\end{array}$} \\
\hline & $\mu \mathrm{m}$ & $p t$ & $\mu \mathrm{m}$ & $p t$ & $\mu \mathrm{m}$ & $p t$ & \\
\hline Body length & 284 & - & 288 & - & $?$ & - & \\
\hline Buccal tube length & 25.8 & - & 25.7 & - & 26.4 & - & \\
\hline Buccal tube width & 10.9 & 42.2 & 10.9 & 42.4 & 10.2 & 38.6 & \\
\hline $\begin{array}{l}\text { Stylet supports } \\
\text { insertion point }\end{array}$ & & 65.5 & & 65.9 & & 63.0 & 2.9 \\
\hline Primary claw I & 10.1 & 39.1 & $?$ & $?$ & $?$ & $?$ & \\
\hline Secondary claw I & 7.3 & 28.3 & $?$ & $?$ & $?$ & $?$ & \\
\hline $\begin{array}{l}\text { Secondary: primary } \\
\text { claw I ratio }\end{array}$ & \multicolumn{2}{|c|}{$72.3 \%$} & \multicolumn{2}{|c|}{ ? } & \multicolumn{2}{|c|}{ ? } & $?$ \\
\hline Primary claw II & 10.9 & 42.2 & 11.3 & 44.0 & 11.7 & 44.3 & \\
\hline Secondary claw II & 7.6 & 29.5 & 8.0 & 31.1 & 8.3 & 31.4 & \\
\hline $\begin{array}{l}\text { Secondary: primary } \\
\text { claw II ratio }\end{array}$ & \multicolumn{2}{|c|}{$69.7 \%$} & \multicolumn{2}{|c|}{$70.8 \%$} & \multicolumn{2}{|c|}{$70.9 \%$} & 1.2 \\
\hline Primary claw III & 11.7 & 45.3 & 11.8 & 45.9 & 11.7 & 44.3 & \\
\hline Secondary claw III & 8.2 & 31.8 & 8.5 & 33.1 & 8.5 & 32.2 & \\
\hline $\begin{array}{l}\text { Secondary: primary } \\
\text { claw III ratio }\end{array}$ & \multicolumn{2}{|c|}{$70.1 \%$} & \multicolumn{2}{|c|}{$72.0 \%$} & \multicolumn{2}{|c|}{$72.6 \%$} & 2.5 \\
\hline Primary claw IV & 13.1 & 50.8 & 13.1 & 51.0 & 13.2 & 50.0 & \\
\hline Secondary claw IV & 8.7 & 33.7 & 8.6 & 33.5 & 9.1 & 34.5 & \\
\hline $\begin{array}{l}\text { Secondary: primary } \\
\text { claw IV ratio }\end{array}$ & \multicolumn{2}{|c|}{$66.4 \%$} & \multicolumn{2}{|c|}{$65.6 \%$} & \multicolumn{2}{|c|}{$68.9 \%$} & 3.3 \\
\hline
\end{tabular}

asiaticum in having wider buccal tube with respect to the body length; a lower posterior primary claw $p t$ ratio, and a slightly higher percent ratio between the secondary claw and primary claw lengths on legs III and IV (Tables 1-2; Figs 1C, D and 2A). These facts led us to conclude that the three Milnesium minutum sp. n. specimens were not young examples of Milnesium asiaticum but, independent of body size, belonged to a distinct species.

In addition to the body size, the new species differs from Milnesium eurystomum and Milnesium bohleberi by having a cylindrical (not funnel-shaped) buccal tube; from Milnesium eurystomum by having a higher $p t$ of the insertion point of the stylet supports ( $p t=63-66$ in Milnesium minutum sp. n. vs 58-61 in Milnesium eurystomum); and from Milnesium bohleberi in having lower percent ratio between the secondary claw and the primary claw lengths on all legs (the percent ratio is 69.7-72.6 in the claws I-III of Milnesium minutum sp. n. and 77.9-84.9, for Milnesium bohleberi (according to Bartels et al. 2014); in claw IV the values are 65.6-68.9 in Milnesium minutum sp. n. and, 78.9-80.4 for Milnesium bohleberi (see: Bartels et al. 2014)). 

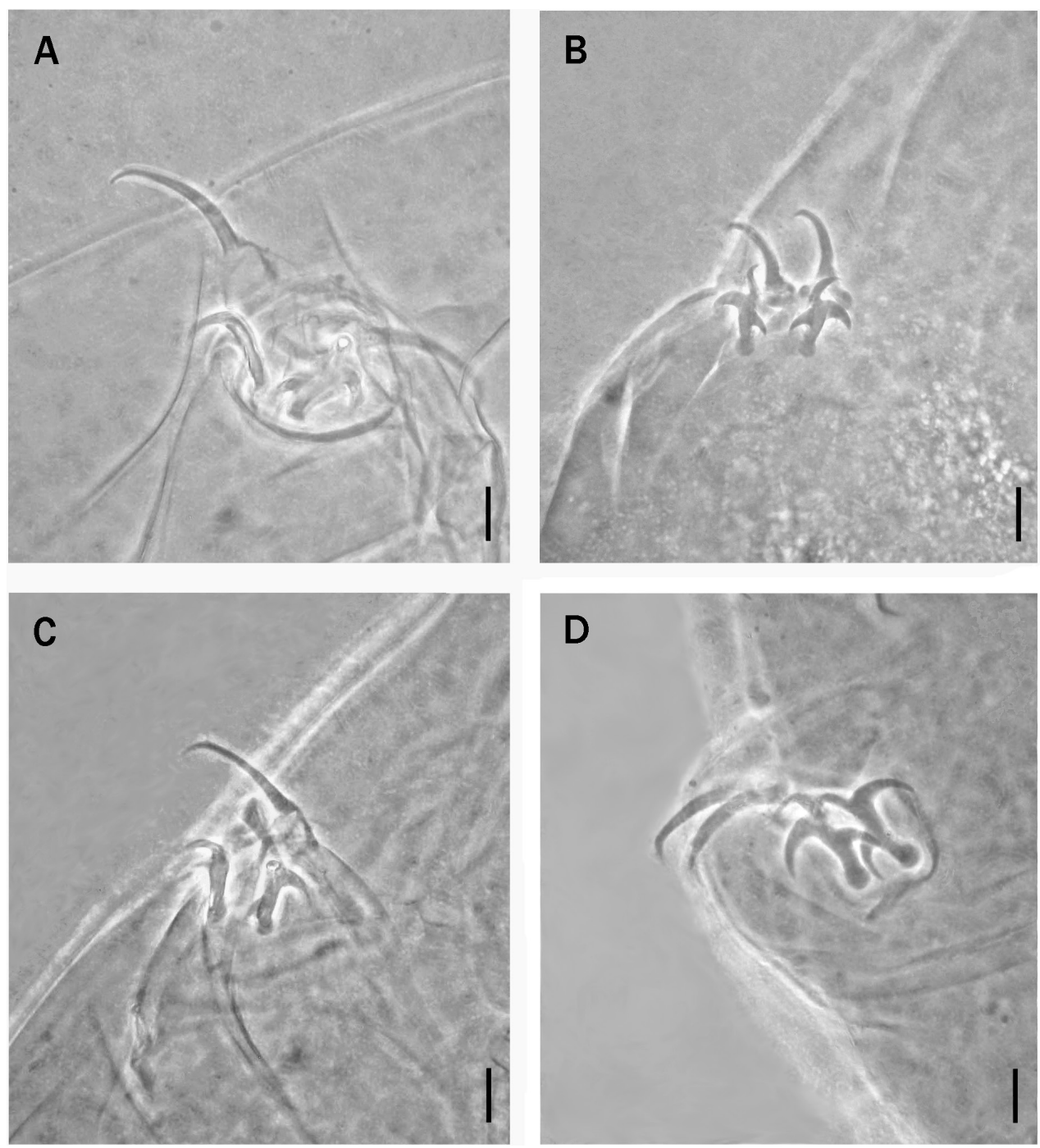

Figure 2. A Claws of the third pair of legs of Milnesium asiaticum. B Claws of the first pair of legs of Milnesium brachyungue $\mathbf{C}$ Claws of the first pair of legs of Milnesium longiungue D Claws of the second pair of legs of Milnesium antarcticum, Scale bars: $10 \mu \mathrm{m}$.

Milnesium minutum sp. n. differs from Milnesium brachyungue by having slightly lower $p t$ of the stylet supports insertion point (63-66 in the new species vs 67-70 in Milnesium brachyungue), by higher $p t$ of the primary and the secondary claw lengths, and by higher values of the percent ratio between the secondary claw and primary claw lengths (Tables 1 and 2, Figs 1 and 2B).

The new species differs from Milnesium longiungue by having accessory points as well as lower $p t$ of the primary claw lengths and higher values of the percent ratio between the secondary claw and primary claw lengths (Tables 1 and 2, Figs 1 and 2C). 
Table 2. Measurements in $\mu \mathrm{m}$, $p t$ index values relative to some structures, and percent ratio between secondary claw and primary claw lengths of a paratype of Milnesium asiaticum, the holotype of Milnesium brachyungue, and a paratype of Milnesium longiungue.

\begin{tabular}{|c|c|c|c|c|c|c|}
\hline \multirow{3}{*}{ Measurements } & \multirow{2}{*}{\multicolumn{2}{|c|}{$\begin{array}{c}\text { M. asiaticum } \\
5105 \\
\text { paratype }\end{array}$}} & \multirow{2}{*}{\multicolumn{2}{|c|}{$\begin{array}{c}\text { M. brachyungue } \\
3940 \\
\text { holotype }\end{array}$}} & \multirow{2}{*}{\multicolumn{2}{|c|}{$\begin{array}{c}\text { M. longiungue } \\
5103 \\
\text { paratype }\end{array}$}} \\
\hline & & & & & & \\
\hline & $\mu \mathrm{m}$ & $p t$ & $\mu \mathrm{m}$ & $p t$ & $\mu \mathrm{m}$ & $p t$ \\
\hline Body length & 685 & - & 801 & - & 747 & - \\
\hline Buccal tube length & 54.0 & - & 59.8 & - & 46.6 & - \\
\hline Buccal tube width & 22.1 & 40.9 & 23.7 & 39.6 & 22.1 & 47.4 \\
\hline $\begin{array}{l}\text { Stylet supports insertion } \\
\text { point }\end{array}$ & & 63.8 & & 69.8 & & 62.3 \\
\hline Primary claw I & 21.8 & 40.4 & 13.9 & 23.2 & 22.5 & 48.3 \\
\hline Secondary claw I & 15.1 & 28.0 & 12.4 & 20.7 & 14.2 & 30.5 \\
\hline Secondary: primary claw I ratio & \multicolumn{2}{|c|}{$69.3 \%$} & \multicolumn{2}{|c|}{$89.2 \%$} & \multicolumn{2}{|c|}{$63.1 \%$} \\
\hline Primary claw II & 24.5 & 45.4 & 15.4 & 25.8 & 25.4 & 55.5 \\
\hline Secondary claw II & 16.0 & 29.6 & 13.3 & 22.2 & 15.2 & 32.6 \\
\hline Secondary: primary claw II ratio & \multicolumn{2}{|c|}{$65.3 \%$} & \multicolumn{2}{|c|}{$86.4 \%$} & \multicolumn{2}{|c|}{$59.8 \%$} \\
\hline Primary claw III & 26.3 & 48.7 & 16.5 & 27.6 & 27.2 & 57.7 \\
\hline Secondary claw III & 16.4 & 30.4 & 14.2 & 23.8 & 16.4 & 35.2 \\
\hline Secondary: primary claw III ratio & \multicolumn{2}{|c|}{$62.4 \%$} & \multicolumn{2}{|c|}{$86.1 \%$} & \multicolumn{2}{|c|}{$60.3 \%$} \\
\hline Primary claw IV & 33.6 & 62.2 & 18.9 & 31.6 & 36.5 & 78.3 \\
\hline Secondary claw IV & 20.5 & 38.0 & 15.4 & 25.8 & 21.5 & 46.2 \\
\hline Secondary: primary claw IV ratio & \multicolumn{2}{|c|}{$61.0 \%$} & \multicolumn{2}{|c|}{$81.5 \%$} & \multicolumn{2}{|c|}{$58.9 \%$} \\
\hline
\end{tabular}

The new species differs from Milnesium antarcticum by having a higher $p t$ of the buccal tube width (38.6-42.4 in Milnesium minutum sp. n., 25.9-31.8 in Milnesium antarcticum according to Tumanov 2006); lower $p t$ of the insertion point of the stylet supports on the buccal tube (63.0-66.0 in the new species, 70.0-73.7 in Milnesium antarcticum according to Tumanov 2006); higher $p t$ of the primary claw lengths on legs I-III (Tables 1 and 4, Figs 1 and 2D).

Milnesium minutum sp. n. differs from Milnesium zsalakoae by the more anterior insertion of the stylet supports on the buccal tube ( $p t=63-66$ in Milnesium minutum sp. n., 68.2-71.1 in Milnesium zsalakoae, according to Meyer and Hinton 2010). The new species also differs by having accessory points and by having a higher percent ratio between the secondary claw and primary claw lengths on legs IV where the values are 65.6-68.9 in Milnesium minutum and 47.2-48.6 for Milnesium zsalakoae (see: Meyer and Hinton 2010).

The new species clearly differs from Milnesium barbadosense by having eyes and by having the stylet supports inserted on the buccal tube in a more anterior position ( $p t$ = 63-66 in the new species, about 73 for Milnesium barbadosense according to Meyer and Hinton 2012) (Tables 1 and 4). 
Milnesium sandrae sp. n.

http://zoobank.org/D17FD526-0722-4D6E-A50A-F855F68110A6

Fig. 3, Table 3

Locus typicus. Hawaiian Archipelago: Hawai'i Island.

Material examined. Hawaiian Archipelago: Hawai'i Island (holotype, slide 4290) and 16 paratypes (slides Nos. 4268, 4288-4290; 4293) collected in 1994 by Dr. D.S. Horning (Sydney).

The precise geographic coordinates relative to the type locality in which the specimens were found in 1994 are not available. The specimens were erroneously considered as Milnesium tardigradum by Binda and Pilato (1994).

Type repository. Holotype and paratypes are deposited in the Binda and Pilato Collection, Museum of the Department of Biological, Geological and Environmental Sciences, University of Catania, Sicily.

Specific diagnosis. Colourless; cuticle smooth; eye spots present; six peribuccal and two lateral papillae present; bucco-pharyngeal apparatus of the Milnesium type. Buccal tube wide; mouth terminal with six peribuccal lamellae. Stylet supports inserted on the buccal tube at 58.0-60.5\% of its length. Claws of the Milnesium type with [3-3]-[3-3] configuration; primary claws with thin accessory points; secondary claws each with a rounded basal thickening (lunule); a long cuticular bar present under the claws I-III.

Description of the holotype. Body $567 \mu \mathrm{m}$ long, colourless, cuticle smooth without pseudopores, reticulum, tubercles or gibbosities; eye spots present. Six peribuccal and two lateral papillae present. Bucco-pharyngeal apparatus of the Milnesium type (Fig. 3A) (rigid buccal tube without ventral lamina, apophyses for the insertion of the stylet muscles in the shape of very short and flat ridges symmetrical with respect to the frontal plane and without caudal processes; pharyngeal bulb elongated, pear-shaped, without apophyses, placoids or septulum); mouth terminal with six triangular peribuccal lamellae with basal stripes. Stylet furcae triangular in shape (Fig. 3A). Buccal tube cylindrical, $35.0 \mu \mathrm{m}$ long; the external width at the level of the stylet supports insertion point is 15.7 $\mu \mathrm{m}(p t=44.9)$. Stylet supports inserted on the buccal tube at $58.0 \%$ of its length.

Claws of the Milnesium type (Fig. 3B-D), secondary claws with three points: configuration [3-3]-[3-3]. Primary claws on legs I, $14.5 \mu \mathrm{m}$ long ( $p t=41.4$ ), and secondary claw, $12.4 \mu \mathrm{m}(p t=35.4)$; primary claws on legs II, $15.2 \mu \mathrm{m}$ long $(p t=43.4)$ and secondary claw, $12.4 \mu \mathrm{m}(p t=35.4)$; primary claws on legs III, $15.2 \mu \mathrm{m}$ long $(p t=43.4)$ and secondary claw, $12.2 \mu \mathrm{m}(p t=34.9)$; primary claws on legs IV, $19.2 \mu \mathrm{m}$ long $(p t=54.9)$ and secondary claw, $13.7 \mu \mathrm{m}(p t=39.1)$. The secondary claw length is $85.5 \%$ of the primary claw length on legs I, $81.6 \%$ on legs II, $80.3 \%$ on legs III and $71.4 \%$ on legs IV.

Thin accessory points present on the primary claws (Fig. 3C, D); secondary claws each with rounded basal thickening (lunule) (Fig. 3C); a long cuticular bar is present under the claws I-III (Fig. 3B).

Remarks. The paratypes are similar to the holotype in both qualitative and quantitative characters (Table 3).

Etymology. The specific name sandrae is in honour of Dr. Sandra J. McInnes (Cambridge, United Kingdom), who kindly improved the English of many of our papers. 

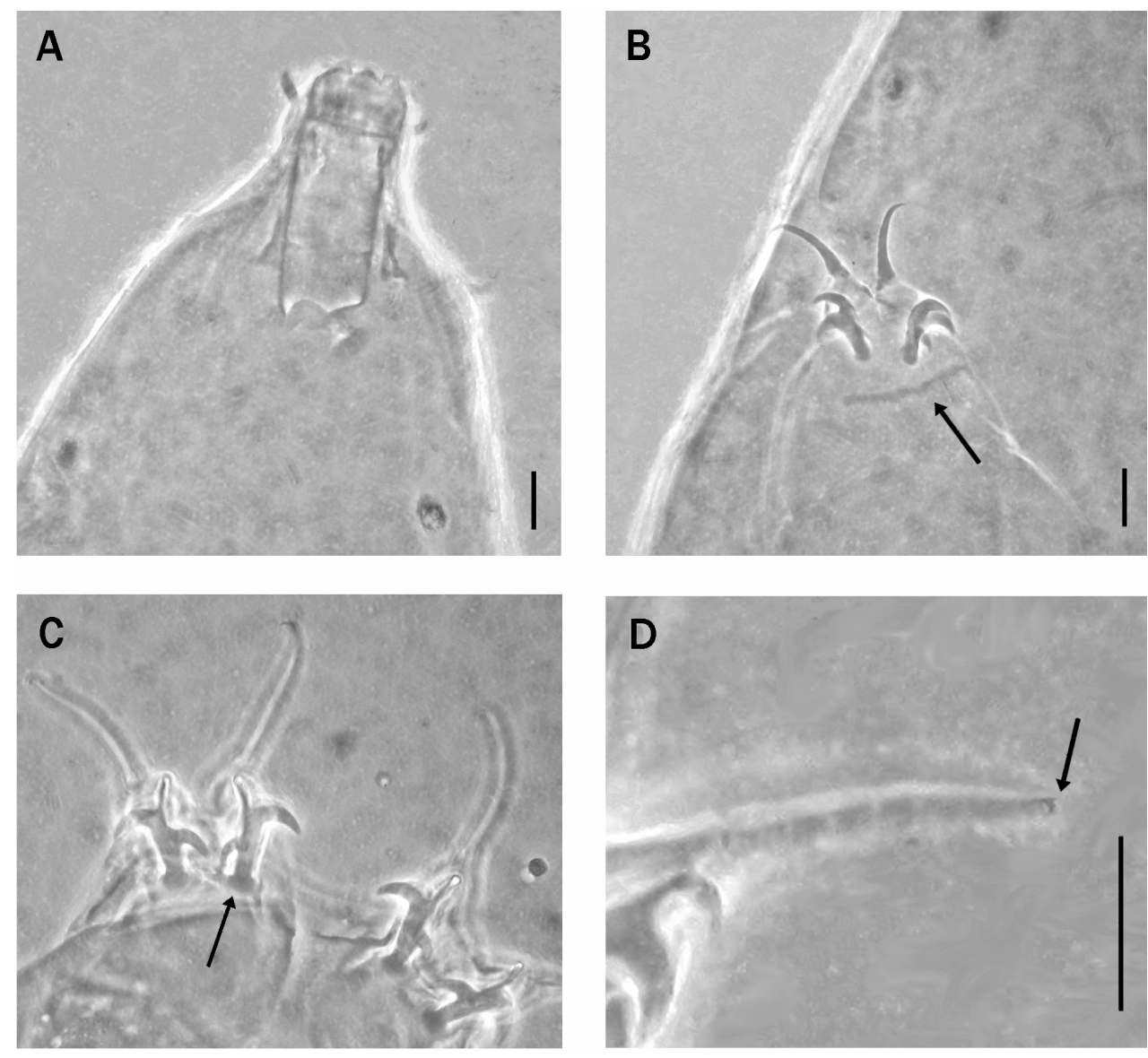

Figure 3. A-D, Milnesium sandrae sp. n. A Bucco-pharyngeal apparatus (holotype) B Claws of the first pair of legs; the arrow indicates the long cuticular thickening (holotype) C Claws of the hind legs; the arrow indicates a claw basal thickening (lunule) (slide No. 1028) D Detail of one claw of the hind legs with an arrow that indicates one accessory point (holotype). Scale bars: $10 \mu \mathrm{m}$.

Differential diagnosis. Milnesium sandrae sp. $n$. is compared with other species of the genus having six peribuccal lamellae, smooth cuticle (without pseudopores, reticulum, tubercles or gibbosities), and the [3-3]-[3-3] claw configuration. The new species differs from all these species, except Milnesium eurystomum, by having a different value of the $p t$ index of the stylet supports insertion point (58.0-60.5 in the new species, over 62 in the remaining taxa) and other characters, which are indicated in detail in the following comparisons.

Milnesium sandrae sp. n. differs from Milnesium eurystomum and Milnesium bohleberi by having a cylindrical instead of a funnel-shaped buccal tube.

Milnesium sandrae sp. n. differs from Milnesium brachyungue by a higher buccal tube width $p t$ index; a higher $p t$ of both the primary and secondary claw lengths, and lower percent ratio values between the secondary claw and primary claw lengths ( $\mathrm{Ta}$ bles 3 and 2, and Figs 3BC and 2B); this ratio difference is particularly marked for legs 
Table 3. Measurements in $\mu \mathrm{m}$, $p t$ index values relative to some structures, and percent ratio between secondary claw and primary claw lengths of the holotype, and three paratypes of Milnesium sandrae sp. $\mathrm{n}$. Also the differences between maximum and minimum values of some characters are given.

\begin{tabular}{|c|c|c|c|c|c|c|c|c|c|}
\hline \multirow{2}{*}{ Slide number } & \multicolumn{2}{|c|}{$\begin{array}{c}4290 \\
\text { Hawai'i Island } \\
\text { paratype }\end{array}$} & \multicolumn{2}{|c|}{$\begin{array}{c}4290 \\
\text { Hawai'i Island } \\
\text { paratype }\end{array}$} & \multicolumn{2}{|c|}{\begin{tabular}{|c|}
4293 \\
Hawai'i Island \\
paratype
\end{tabular}} & \multicolumn{2}{|c|}{$\begin{array}{c}4290 \\
\text { Hawai'i Island } \\
\text { holotype }\end{array}$} & \multirow{2}{*}{$\begin{array}{c}\text { Difference between } \\
\text { Max.-Min. } \\
\text { values }\end{array}$} \\
\hline & $\mu \mathrm{m}$ & $p t$ & $\mu \mathrm{m}$ & $p t$ & $\mu \mathrm{m}$ & $p t$ & $\mu \mathrm{m}$ & $p t$ & \\
\hline Body length & 401 & - & 504 & - & 522 & - & 567 & - & 166 \\
\hline Buccal tube length & 28.6 & - & 33.3 & - & 36.3 & - & 35.0 & - & \\
\hline Buccal tube width & 13.7 & 47.9 & 16 & 48.0 & 16.4 & 45.2 & 15.7 & 44.9 & \\
\hline $\begin{array}{l}\text { Stylet supports } \\
\text { insertion point }\end{array}$ & & 60.5 & & 58.6 & & 58.5 & & 58.0 & 2.5 \\
\hline Primary claw I & $?$ & $?$ & 14.5 & 43.5 & 14.1 & 38.8 & 14.5 & 41.4 & \\
\hline Secondary claw I & 9.7 & 33.9 & $?$ & $?$ & 11.9 & 32.8 & 12.4 & 35.4 & \\
\hline $\begin{array}{l}\text { Secondary: primary } \\
\text { claw I ratio }\end{array}$ & \multicolumn{2}{|c|}{ ? } & & \multicolumn{2}{|c|}{$84.4 \%$} & \multicolumn{2}{|c|}{$85.5 \%$} & 1.1 \\
\hline Primary claw II & 12.5 & 43.7 & 15.5 & 46.6 & 15.4 & 42.4 & 15.2 & 43.4 & \\
\hline Secondary claw II & 10.3 & 36.0 & 12.6 & 37.8 & 12.1 & 33.3 & 12.4 & 35.4 & \\
\hline $\begin{array}{l}\text { Secondary: primary } \\
\text { claw II ratio }\end{array}$ & \multicolumn{2}{|c|}{$82.4 \%$} & \multicolumn{2}{|c|}{$81.3 \%$} & \multicolumn{2}{|c|}{$78.6 \%$} & \multicolumn{2}{|c|}{$81.6 \%$} & 3.8 \\
\hline Primary claw III & 13.2 & 46.1 & 15.0 & 45.0 & 15.8 & 43.5 & 15.2 & 43.4 & \\
\hline Secondary claw III & 10.5 & 36.7 & 12.2 & 36.6 & 12.6 & 34.7 & 12.2 & 34.9 & \\
\hline $\begin{array}{l}\text { Secondary: primary } \\
\text { claw III ratio }\end{array}$ & \multicolumn{2}{|c|}{$79.5 \%$} & \multicolumn{2}{|c|}{$81.3 \%$} & \multicolumn{2}{|c|}{$79.7 \%$} & \multicolumn{2}{|c|}{$80.3 \%$} & 1.8 \\
\hline Primary claw IV & $?$ & $?$ & 19.0 & 57.1 & 19.6 & 54.0 & 19.2 & 54.9 & \\
\hline Secondary claw IV & $?$ & $?$ & 13.4 & 40.2 & 13.8 & 38.0 & 13.7 & 39.1 & \\
\hline $\begin{array}{l}\text { Secondary: primary } \\
\text { claw IV ratio }\end{array}$ & \multicolumn{2}{|c|}{ e } & \multicolumn{2}{|c|}{$70.5 \%$} & \multicolumn{2}{|c|}{$70.4 \%$} & \multicolumn{2}{|c|}{$71.4 \%$} & 1.0 \\
\hline
\end{tabular}

IV where the ratio values of 70.4-71.4 for Milnesium sandrae sp. n. compare with 81 in Milnesium brachyungue (Tables 2 and 3).

The new species differs from Milnesium asiaticum by having a higher $p t$ of the buccal tube width; a higher $p t$ of the secondary claw lengths (particularly on the legs I-III), and a higher percent ratio between the secondary claw and primary claw lengths on all legs (Tables 2 and 3 ).

Milnesium sandrae sp. $\mathrm{n}$. differs from Milnesium antarcticum by having a shorter buccal tube with respect to the body length; a higher $p t$ index of the buccal tube width; higher $p t$ of the insertion point of the stylet supports on the buccal tube (58.060.5 in Milnesium sandrae sp. n., 70.0-73.7 in Milnesium antarcticum according to Tumanov 2006); higher $p t$ indices of the secondary claws, and higher values of the percent ratio between the secondary claw and primary claw lengths (Tables 3 and 4, Figs 3B, C and 2D).

The new species differs from Milnesium longiungue by having accessory points; by having lower $p t$ values of the primary claw, and by a higher percent ratio between the secondary claw and primary claw lengths on all legs (Tables 3 and 4). 
Table 4. Measurements in $\mu \mathrm{m}, p t$ index values relative to some structures, and percent ratio between secondary claw and primary claw lengths of the holotype of Milnesium barbadosense (*According to Meyer and Hinton 2012) and the holotype of Milnesium antarcticum (** according to Tumanov 2006).

\begin{tabular}{|c|c|c|c|c|}
\hline \multirow[b]{3}{*}{ Measurements } & \multirow{2}{*}{\multicolumn{2}{|c|}{$\begin{array}{c}\text { M. barbadosense } \\
\text { holotype }^{*}\end{array}$}} & \multirow{2}{*}{\multicolumn{2}{|c|}{$\begin{array}{c}\text { M. antarcticum } \\
\text { holotype }^{* *}\end{array}$}} \\
\hline & & & & \\
\hline & $\mu \mathrm{m}$ & $p t$ & $\mu \mathrm{m}$ & $p t$ \\
\hline Body length & 686.4 & - & $?$ & - \\
\hline Buccal tube length & 44.0 & - & 74.7 & - \\
\hline Buccal tube width & 21.7 & 49.3 & 27.4 & 36.7 \\
\hline Stylet supports insertion point & & 72.8 & & 71.3 \\
\hline Primary claw I & 17.8 & 40.5 & 26.3 & 35.2 \\
\hline Secondary claw I & 12.3 & 28.0 & 17.8 & 23.8 \\
\hline Secondary: primary claw I ratio & \multicolumn{2}{|c|}{$69.1 \%$} & \multicolumn{2}{|c|}{$67.7 \%$} \\
\hline Primary claw II & 21.6 & 49.1 & $?$ & $?$ \\
\hline Secondary claw II & 14 & 31.8 & $?$ & $?$ \\
\hline Secondary: primary claw II ratio & \multicolumn{2}{|c|}{$64.8 \%$} & \multicolumn{2}{|c|}{ ? } \\
\hline Primary claw III & 21.1 & 48.0 & $?$ & $?$ \\
\hline Secondary claw III & 12.3 & 28.0 & $?$ & $?$ \\
\hline Secondary: primary claw III ratio & \multicolumn{2}{|c|}{$58.3 \%$} & \multicolumn{2}{|c|}{ ? } \\
\hline Primary claw IV & 23.3 & 53.0 & 39.2 & 52.5 \\
\hline Secondary claw IV & 16.0 & 36.4 & 23.7 & 31.7 \\
\hline Secondary: primary claw IV ratio & \multicolumn{2}{|c|}{$68.7 \%$} & \multicolumn{2}{|c|}{60.5} \\
\hline
\end{tabular}

The new species differs from Milnesium zsalakoae in having accessory points and a higher percent ratio between the secondary claw and primary claw lengths on all legs. The difference is particularly marked in claws IV where the $p t$ ratios are 70.4-71.4 in Milnesium sandrae sp. n. and 47.2-48.6 in Milnesium zsalakoae (see: Meyer and Hinton 2010).

Milnesium sandrae sp. n. differs from Milnesium barbadosense by higher $p t$ of the secondary claw lengths and by higher values of the percent ratio between the secondary claw and the primary claw lengths on legs I-III (Tables 3 and 4).

Milnesium sandrae sp. n. differs from Milnesium minutum by having a larger body size; shorter buccal tube with respect to the body length; a higher $p t$ of the secondary claw lengths and higher values of the percent ratio between the secondary claw and primary claw lengths. This difference is less marked in legs IV (Tables 1 and 3; Figs 1 and 3).

\section{Conclusions}

The description of two new species, Milnesium minutum sp. n. and Milnesium sandrae sp. n., raises the number of species ascribed to the genus Milnesium to 31 (30 living and one fossil). Therefore, this tardigrade genus, considered monospecific for 150 years (1840-1990), today is among the 10 most species rich genera. The first species described, Milnesium tardigradum Doyère, 1840, was considered cosmopolitan, but it is evident that specimens of many species have been erroneously attributed to Milnesium 
tardigradum and, therefore, its geographic distribution must be re-examined and it is probable that the distribution of Milnesium tardigradum is much smaller than formerly believed (Michalczyk et al. 2012a). Many of the newly described species of Milnesium have been reported from only one locality, but it is possible that some of them will be recognized in the future in other geographic areas. Therefore the actual geographic distribution of many species of Milnesium has to be considered provisional.

\section{Acknowledgements}

We are very grateful to Dr. Denis Tumanov (St. Petersburg, Russia), who sent us specimens of some studied species, and Prof. Dr. Diane Nelson (Johnson City, Tennessee) for reviewing the English of the text.

\section{References}

Bartels PJ, Nelson DR, Kaczmarek Ł, Michalczyk Ł (2014) The genus Milnesium (Tardigrada: Eutardigrada: Milnesiidae) in the Great Smoky Mountains National Park (North Carolina and Tennessee, USA) with the description of Milnesium bohleberi sp. n. Zootaxa 3826(2): 356-368. doi: 10.11646/zootaxa.3826.2.5

Binda G, Pilato G (1990) Tardigradi della Terra del Fuoco e Magallanes. Milnesium brachyungue, nuova specie di tardigrado Milnesiidae. Animalia 17: 105-110.

Binda MG, Pilato G (1994) Notizie sui Tardigradi delle Isole Hawaii con descrizione di due specie nuove. Animalia 21: 57-62.

Doyère LMF (1840) Mémoire sur les Tardigrades. I.Annales des Sciences Naturelles (Paris S. 2) 14: 269-362.

Maucci W (1991) Tre nuove specie di Eutardigradi della Groenlandia Meridionale. Bollettino del Museo Civico di Storia Naturale di Verona 15: 279-289.

Meyer HA, Hinton JG (2010) Milnesium zsalakoae and Milnesium jacobi, two new species of Tardigrada (Eutardigrada: Milnesiidae) from the southwestern USA. Proceedings of the Biological Society of Washington 123(2): 113-120. doi: 10.2988/09-29.1

Meyer HA, Hinton JC (2012) Terrestrial Tardigrada of the island of Barbados in the West Indies, with the description of Milnesium barbadosense sp. n. (Eutardigrada: Apochela: Milnesiidae). Caribbean Journal of Science 46(2-3): 194-202.

Michalczyk Ł, Wełnicz W, Frohme M, Kaczmarek Ł (2012) Redescription of Milnesium Doyère, 1840 taxa (Tardigrada: Eutardigrada: Milnesiidae), including the nominal species for the genus. Zootaxa 3154: 1-20.

Michalczyk Ł, Wełnicz W, Frohme M, Kaczmarek Ł (2012b) Corrigenda of Zootaxa, 3154: 1-20 Redescriptions of three Milnesium Doyère, 1840 taxa (Tardigrada: Eutardigrada: Milnesiidae), including the nominal species for the genus. Zootaxa 3154: 1-20.

Pilato G (1981) Analisi di nuovi caratteri nello studio degli Eutardigradi. Animalia 8: 51-57.

Tumanov DV (2006) Five new species of the genus Milnesium (Tardigrada, Eutardigrada, Milnesiidae). Zootaxa 1122: 1-23. 